\title{
Empowerment of Health Volunteer through the Training using Module of Health Volunteer Guidance: Children under Five Years Health Problem during Disaster
}

\author{
Suprajitno \\ Nursing Department, Poltekkes Malang \\ suprajitno_skp@poltekkes-malang.ac.id
}

\author{
Sri Mugianti \\ Nursing Department, Poltekkes Malang \\ sri_mugianti@poltekkes-malang.ac.id
}

\begin{abstract}
Balita (children under five years) susceptible to health problems during the evacuation at disaster. Health professional personnel have more duties and responsibilities during a disaster; so that health volunteer can be empowered to identify children under five years old health problems. The goal was health volunteer can be the identification of children under five years old health problem during a disaster. Methods: The design was pre-post test only one group by training was using the module. The training conducted three times was August 10, August 30, and September 15, 2016. Place in the meeting room of Kampung Melon Desa Wisata Modangan (Village of Melon of Tourism Village) of Nglegok Blitar. Ref [1] The module title was Modul Pegangan Kader Kesehatan: Masalah Kesehatan Balita Saat Bencana (Module of Health Volunteer Guidance: Balita Health Problem during Disaster) ISBN 978-602-6931-84-9. Training method used are brainstorming, lectures, simulations, and demonstrations. The population consisted of 45 health volunteer. The Sample consisted of 39nperson health volunteer of Modangan village of Nglegok Blitar. Data collection used questionnaire and checklist prepared training materials. Data were Analyzed used descriptive of central tendency. The results were the average of health volunteer knowledge change from $\mathbf{5 . 3}$ +2.45 to $7.9+1.04$ and standard deviation change of $42.45 \%$. Average of ability to identify with eight indicator measures was increase as many as $12.16 \%(72.63 \%$ to $84.79 \%)$. Recommended: The module used in training by health volunteers in this situation is similar to the rural area of Modangan Nglegok Blitar.
\end{abstract}

Keywords: health volunteer, module, training, knowledge, ability

\section{INTRODUCTION}

Blitar is slopes of Kelud volcano. The last eruption occurred in the year of 1966, 1990, and 2014. Time of the eruption, the people of Modangan village of Nglegok Blitar had to evacuate in the barrack prepared, including health volunteer (community health volunteer). Over the barrack, duties and responsibilities of a health professional are increasing. All people who are at risk, including children under five years. Health services, especially health volunteers have identified children under-five years health. However, health volunteer, should have the knowledge and skills to the identification of children under five years old health vulnerable as in [2]. Improving the knowledge and skills of health Volunteer can be done by training that is done using the module. The goal was increasing of health Volunteer knowledge and skills to the identification of children under five years health disturbed when disaster Ease of Use

\section{METHOD}

The design was pre-post test only one group, as the community service activities of the tri dharma college. The module title was Modul Pegangan Kader Kesehatan: Masalah Kesehatan Balita Saat Bencana (Module of Health Volunteer Guidance: Children under five years Health Problem When Disaster) ISBN 978-602-6931-84-9 as in [3]. The training conducted three times were August 10, August 30, and September 15, 2016; used are brainstorming, lectures, simulations, and demonstrations as in [4]. Place in the meeting room of Kampung Melon Desa Wisata Modangan (Village of Melon of Modangan Tourism Village) of Nglegok Blitar. Trainers were 39 of 45 person health Volunteer of Modangan village of Nglegok Blitar. Data collection used questionnaire and checklist prepared training materials. The data were analyzed use descriptive of central tendency.

\section{RESULT}

Characteristic, knowledge, and ability of health Volunteer trainee tabulated below.

TABLE I. KNOWLEDGE OF HEALTH VOLUNTEER MODANGAN VILLAGE BEFORE AND AFTER TRAINING

\begin{tabular}{cccc}
\hline No. & Component & Before & After \\
\hline 1 & $\begin{array}{c}\text { Some correct answers: } \\
\text { Minimum and Maximum }\end{array}$ & & \\
& & $5 / 7$ & $7 / 9$ \\
2 & Average and Standard & $5.3 / 2.45$ & $7.9 / 1.04$ \\
deviation & & \\
3 & Median and Mode & $5 / 5$ & $8 / 7$ \\
\hline \multicolumn{2}{c}{ Standard deviation change } & \multicolumn{2}{c}{$42.45 \%$} \\
\hline
\end{tabular}


TABLE II. HEALTH VOLUNTEER CHARACTERISTIC OF MODANGAN VILLAGE

\begin{tabular}{|c|c|c|c|}
\hline No. & Characteristic & $\mathbf{f}$ & $\%$ \\
\hline 1 & Sex: Female & 39 & 100.0 \\
\hline 2 & $\begin{array}{c}\text { Married status: } \\
\text { - single } \\
\text { - married }\end{array}$ & $\begin{array}{c}3 \\
36\end{array}$ & $\begin{array}{c}7.7 \\
92.3\end{array}$ \\
\hline 3 & $\begin{array}{c}\text { Length as health Volunteer } \\
\text { - less than five years } \\
\text { - } 5 \text { to } 10 \text { years } \\
\text { - more than ten years }\end{array}$ & $\begin{array}{c}3 \\
23 \\
13\end{array}$ & $\begin{array}{c}7.7 \\
58.9 \\
33.4\end{array}$ \\
\hline 4 & $\begin{array}{c}\text { Experience training: } \\
\text { - never } \\
\text { - once - three times } \\
\text { - more than three time }\end{array}$ & $\begin{array}{c}3 \\
9 \\
27\end{array}$ & $\begin{array}{c}7.7 \\
23.0 \\
69.3\end{array}$ \\
\hline 5 & $\begin{array}{l}\text { Experience training of } \\
\text { children under five years } \\
\text { health disturbed: } \\
\text { - never }\end{array}$ & 39 & 100.0 \\
\hline 6 & \multicolumn{3}{|c|}{$\begin{array}{c}\text { Aged: } \\
\text { - range: } 20 \text { to } 58 \text { years old }\end{array}$} \\
\hline
\end{tabular}

TABLE III THE ABILITY TO ACT OF HEALTH VOLUNTEER MODANGAN VILLAGE BEFORE AND AFTER TRAINING

\begin{tabular}{|c|c|c|c|}
\hline No. & The ability to actions & Before & After \\
\hline 1 & $\begin{array}{l}\text { How to measure the children } \\
\text { under five years nutritional } \\
\text { status }\end{array}$ & $\mathbf{7 8 . 5} \%$ & $84.8 \%$ \\
\hline 2 & $\begin{array}{c}\text { Identification of balita } \\
\text { nutritional status }\end{array}$ & $62.4 \%$ & $69.2 \%$ \\
\hline 3 & $\begin{array}{c}\text { How to supply the nutritional } \\
\text { needs of children under five } \\
\text { years }\end{array}$ & $76.3 \%$ & $87.2 \%$ \\
\hline 4 & $\begin{array}{l}\text { How to identify children } \\
\text { under five years eye health }\end{array}$ & $74.3 \%$ & $88.3 \%$ \\
\hline 5 & $\begin{array}{l}\text { How to eyes care of children } \\
\text { under five years who suffered } \\
\text { health problems }\end{array}$ & $64.8 \%$ & $91.2 \%$ \\
\hline 6 & $\begin{array}{l}\text { How to identify the balita } \\
\text { body temperature }\end{array}$ & $87.3 \%$ & $88.5 \%$ \\
\hline 7 & $\begin{array}{l}\text { Measuring children under } \\
\text { five years (fluid needs that } \\
\text { have problems }\end{array}$ & $62.1 \%$ & $86.4 \%$ \\
\hline 8 & $\begin{array}{l}\text { How to supply the fluid needs } \\
\text { of children under five years } \\
\text { health problems }\end{array}$ & $75.4 \%$ & $82.7 \%$ \\
\hline & Average & $72.63 \%$ & $84.79 \%$ \\
\hline
\end{tabular}

\section{DISCUSSION}

Health Volunteer were someone who provide services in Posyandu (Pos Pelayanan Terpadu/place of integrated service) has been since the 1980s in Indonesia after proclaimed of PHC (Primary Health Care) as the agreement of Alma Ata on 1978 requiring the importance of communities' active participation. Health Volunteer role is a provider of Posyandu services related to population and or health allied. As in Posyandu service used five tables system, that is the first table: registration, the second table: Weighing weight of children under five years the third table: health volunteer-written of children under five years weight to KMS (Kartu Menuju Sehat / Healthy Card), the fourth table: Health Volunteer provided of health education and supplementary feeding, and the fifth table: services by health professional (nurse or midwifery) as in[5]. Posyandu targets are children under five years, pregnant, breastfeed mother and family planning.

There are three person Health Volunteer who have never training of Posyandu because they are a new health Volunteer. The reason of being a health volunteer is substituted her mother who has more than 60 years old. All health volunteers of Modangan village had never received training on the identification and handling of children under five years who have health problems during a disaster, although it has twice timed the experience of the Kelud eruption in 1990 and 2014. Health volunteer of Modangan village needs to improve services when a disaster occurs. Reasoning, Modangan village on the slopes of the Kelud volcano and called 2nd disaster-prone zone. Training to health volunteer is highly effective because it can improve the knowledge and ability to provide services. Ref [6] describes as follows:

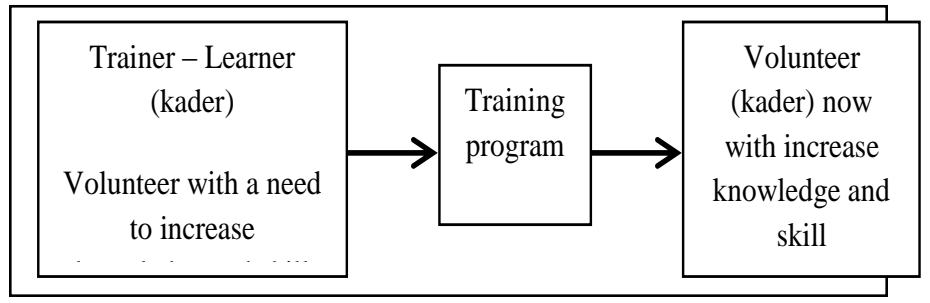

Fig. 1. Illustrated of their status and potential richness (Source: Lewis, 2006: 19-20)

Training undertaken must answer why and who as in as in[6]. The 'why' motivates the trainer contributing to the learning experience to embrace the learning and draw on the necessary resources. The 'who' require knowing the prospective trainees and describing a target as in [7]

Training can improve the knowledge and ability of health volunteer in identifying infant health problems in times of disaster as in [2]. Trained using lectures, simulations, and demonstrations can increase the health volunteer capability as in [5]. That capability is cognitive, affective, and psychomotor as in [5]. So, it can improve the gradual adoption process as in [5].

\section{CONCLUSION:}

Training using modules for health volunteer of Kampung Melon Desa Wisata Modangan (Village of Melon of Modangan Tourism Village) of Nglegok Blitar can be enhancing the knowledge of $42.45 \%$ and the ability to actions of $12.16 \%$.

The module can be used as a material for the health volunteer training in the other place if the situation and 
circumstances that are similar to Modangan Village of Nglegok Blitar.

\section{REFERENCE}

[1] D. H. Bankoff, G., G. Frerks, Disasters, Development, and People (eds.). Mapping Vulnerability, 2003.

[2] D. Kranke, A. R. Gable, E. L. Weiss, and A. Dobalian, "?I?m in a good place now?: A case study of empowerment of a combat veteran engaged in peer-led disaster relief," Soc. Work Ment. Health, pp. 1-14, Mar. 2017.

[3] D. RI, Buku Pegangan Kader, seri PSM No. 1 dan 2. Jakarta: Depkes, 1987.

[4] Suprajitno, Modul Pegangan Kader Kesehatan: Masalah Kesehatan Balita Saat Bencana. Malang: Media Nusa Creative Publishing., 2016.

[5] S. Notoatmodjo, Pengantar Pendidikan Kesehatan dan Ilmu Perilaku. Jakarta: Rineka Cipta., 2003.

[6] Lewis Hughes, "A Guide for Training Volunteers (Part A)," 2006. [Online]. Available: http://www.volunteeringaustralia.org/wpcontent/files_mf/1377052716VaGuidetotrainingvolunteerspartA.pdf.

[7] S. Kane et al., "Limits and opportunities to community health worker empowerment: A multi-country comparative study," Soc. Sci. Med., vol. 164, pp. 27-34, Sep. 2016. 